\title{
The Age and Origin of the Little Diomede Island Upland Surface
}

\author{
LYN GUALTIERI ${ }^{1}$ and JULIE BRIGHAM-GRETTE ${ }^{2}$
}

(Received 2 July 1999; accepted in revised form 25 May 2000)

\begin{abstract}
Geomorphology and projected uplift rates indicate that the upland surface of Little Diomede Island may represent a high sea level stand that occurred 2.6 million years ago in the Bering Strait. The 350-363 m upland surface of the island could be correlative with the York terrace, an uplifted marine terrace previously recognized on the southern flanks of the York Mountains, Seward Peninsula. The modern surface of Little Diomede Island is composed of a cryoplanation terrace enclosing a central blockfield and rimmed with tors. Beryllium-10 cosmogenic isotope analysis of two tors and three outcrops from the upper surface indicate the island has been under the influence of a subaerial periglacial environment at least for the last 36000 years (MIS 3) and probably for 254000 (MIS 7/8). Unequivocal evidence does not exist to support glaciation of Little Diomede Island.
\end{abstract}

Key words: Little Diomede Island, Bering Strait, York terrace, cosmogenic isotope dating, beryllium-10

RÉSUMÉ. La géomorphologie et les taux d'exhaussement obtenus par extrapolation révèlent que la surface de haute terre de l'île de Petite Diomède pourrait représenter un relief ayant existé dans le contexte d'un niveau de mer élevé qui avait cours il y a 2,6 millions d'années dans le détroit de Béring. La surface de haute terre de l'île, atteignant de 350 à $363 \mathrm{~m}$, pourrait être en corrélation avec la terrasse de York, terrasse marine surélevée, découverte antérieurement sur les flancs méridionaux des monts York situés dans la péninsule Seward. La surface actuelle de l'île de Petite Diomède se compose d'une terrasse de cryoplanation entourant un champ central de blocs rocheux et circonscrite par des tors. L'analyse isotopique cosmogonique au ${ }^{10}$ béryllium de deux tors et de trois affleurements de la surface la plus haute révèle que l'île a subi l'influence d'un environnement périglaciaire subaérien pendant au moins les 36000 dernières années ( $3^{\mathrm{e} e ́ t a g e ~ i s o t o p i q u e ~ m a r i n) ~ e t ~ p r o b a b l e m e n t ~} 254000$ ans $\left(7^{\circ} / 8^{e}\right.$ étage isotopique marin). On ne possède pas de preuve non équivoque d'une glaciation de l'île de Petite Diomède.

Mots clés: île de Petite Diomède, détroit de Béring, terrasse de York, datation cosmogonique aux isotopes, ${ }^{10}$ béryllium

Traduit pour la revue Arctic par Nésida Loyer.

\section{INTRODUCTION}

Although it is widely accepted that the Bering Strait repeatedly served as the central part of the Bering Land Bridge connecting Asia and North America (Hopkins, 1967), the Pleistocene history of the Diomede Islands, situated at the narrowest part of the Bering Strait, has remained unstudied. Little Diomede Island $\left(65^{\circ} 45^{\prime} \mathrm{N}\right.$, $168^{\circ} 56^{\prime} \mathrm{W}$ ) is located $43 \mathrm{~km}$ west of Cape Prince of Wales, Alaska, and $4 \mathrm{~km}$ east of Big Diomede Island, Russia (Fig. 1). At numerous times in the past, sea level has lowered and the Bering Strait has become emergent, forming a land bridge between the two continents. This research details the evolution of a remnant of the central former land bridge (the Little Diomede Island upland surface). The main objective is to answer two questions: 1) Is the upland surface of Little Diomede Island marine, glacial, or periglacial in origin? and 2) What is the age of this surface?

\section{STUDY AREA}

Little Diomede Island is $3 \mathrm{~km}^{2}$ and rises steeply on all sides from sea level to an undulating plain at $350-363 \mathrm{~m}$ (Fig. 2). The village of Inalik (pop. 150) is located on the west side of the island. Historical records indicate that the region is currently submerging. Possibly as late as 135 years ago, a sand spit connected the Little and Big Diomede Islands, with an ephemeral river separating them (Jenness, 1929; C. Ahkinga, pers. comm. 1997).

The regional climate is characterized as subarctic and dominated by extratropical cyclones and arctic anticyclones in winter (Sharma, 1974). The Aleutian Low predominates, causing frequent storms, wind, fog, and precipitation. Because of the cyclonic circulation, the eastern half of the Bering Sea is warmer than the western half; however, the deep southern and western parts of the Bering Sea are generally kept ice-free by

\footnotetext{
${ }^{1}$ Quaternary Research Center, Box 351360, University of Washington, Seattle, Washington 98195-1360, U.S.A.; lyn4@u.washington.edu

${ }^{2}$ Department of Geosciences, University of Massachusetts, Amherst, Massachusetts 01003, U.S.A.

(C) The Arctic Institute of North America
} 


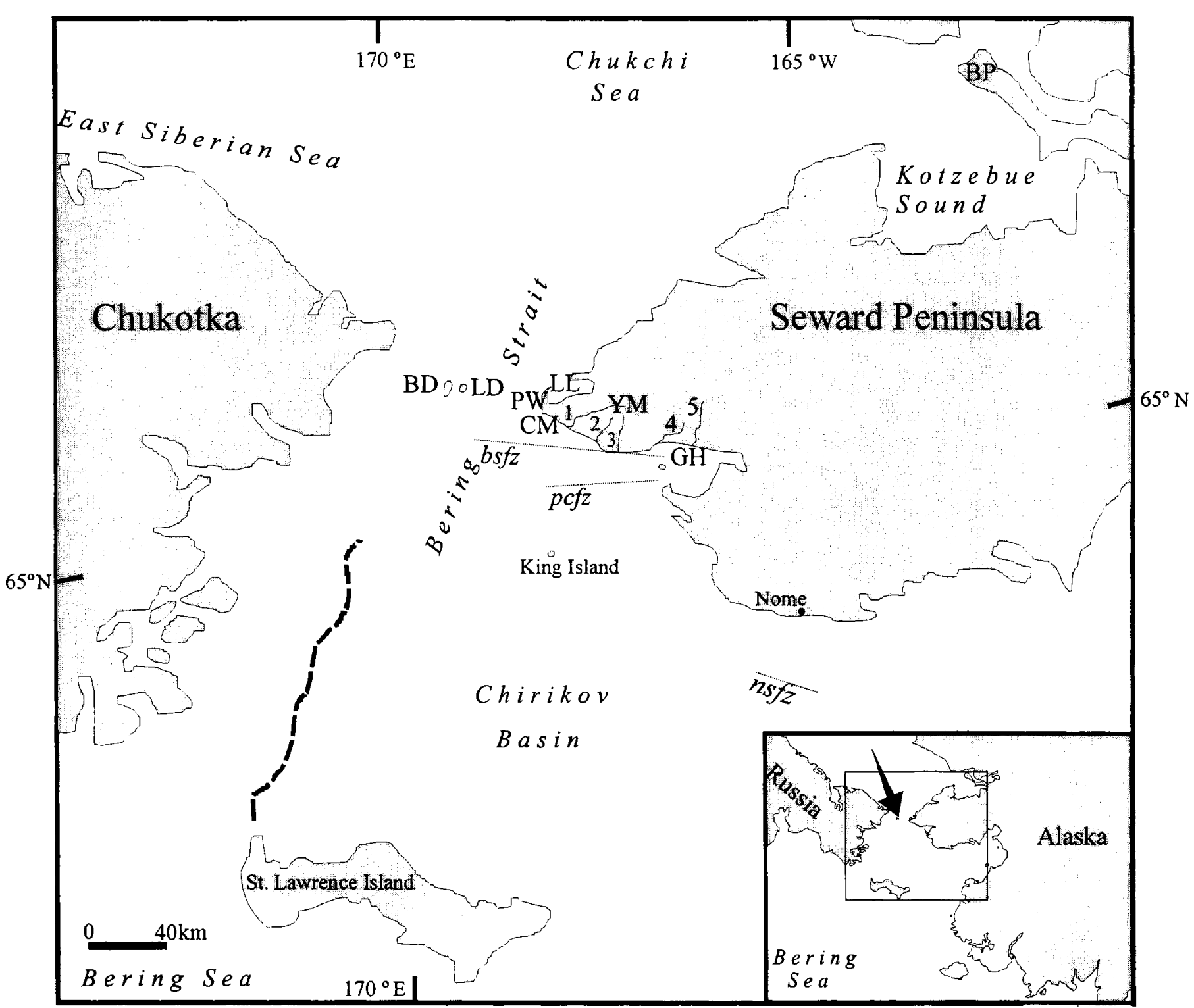

FIG. 1. The Bering Strait region. Arrow on inset shows location of the Diomede Islands and box encloses the enlarged area. Place names are: LD = Little Diomede Island, BD = Big Diomede Island, PW = Cape Prince of Wales, CM = Cape Mountain (site of the York terrace), LL = Lopp Lagoon, YM = York Mountains, GH = Grantley Harbor, BP = Baldwin Peninsula, $1=$ Kanauguk River, 2 = King River, $3=$ Lost River, $4=$ Skull Creek, $5=$ California River. Dashed line north of St. Lawrence Island is the offshore linear ridge interpreted by Grim and McManus (1970) and D.M. Hopkins (pers. comm. 1997) to be a moraine. Thin black lines indicate fault zones: $b s f z=$ Bering Strait Fault Zone, $p c f z=$ Port Clarence Fault Zone, $n s f z=$ Norton Sound Fault Zone (from Plafker et al., 1993).

encroachment of warm Pacific water (Sharma, 1974). The maximum sea ice cover in the Bering Strait is in late winter-early spring, while the Strait is generally ice-free from July to September (Grebmeier et al., 1995). Temperatures on Little Diomede Island average 5 to $10^{\circ} \mathrm{C}$ in summer and -23 to $-14^{\circ} \mathrm{C}$ in winter. Winds are predominantly from the north and average $8 \mathrm{~m} / \mathrm{s}$, with gusts up to $26-36 \mathrm{~m} / \mathrm{s}$ (Alaska Department of Community \& Economic Development, 1998). In July 1997, snow banks were present on north-facing slopes of Little Diomede Island, as well as on the east-facing slopes of Big Diomede Island. The north-, south-, and west-facing slopes of Big Diomede Island could not be seen or investigated; however, it is possible that latelying snowpacks exist on these slopes of Big Diomede
Island also. The island lies within a zone of discontinuous permafrost (Brown et al., 1997).

The first geologic mapping of the island was by Sainsbury (1972), who determined that it consisted of medium- to coarse-grained, unfoliated biotite hornblende granite of late Cretaceous age. Barker et al. (1994) mapped the island as late Cretaceous granite (97-66 million years old). The predominant granite on the island contains feldspar crystals up to $5 \mathrm{~cm}$ long in a coarse-grained matrix of quartz, biotite, and hornblende. The granite has been named the Diomede pluton and is of similar age and lithology as other plutons of the York terrane (Big Diomede Island, King Island) in the Bering Strait and on western Seward Peninsula (Barker et al., 1994; D.M. Hopkins, pers. comm. 1997). 


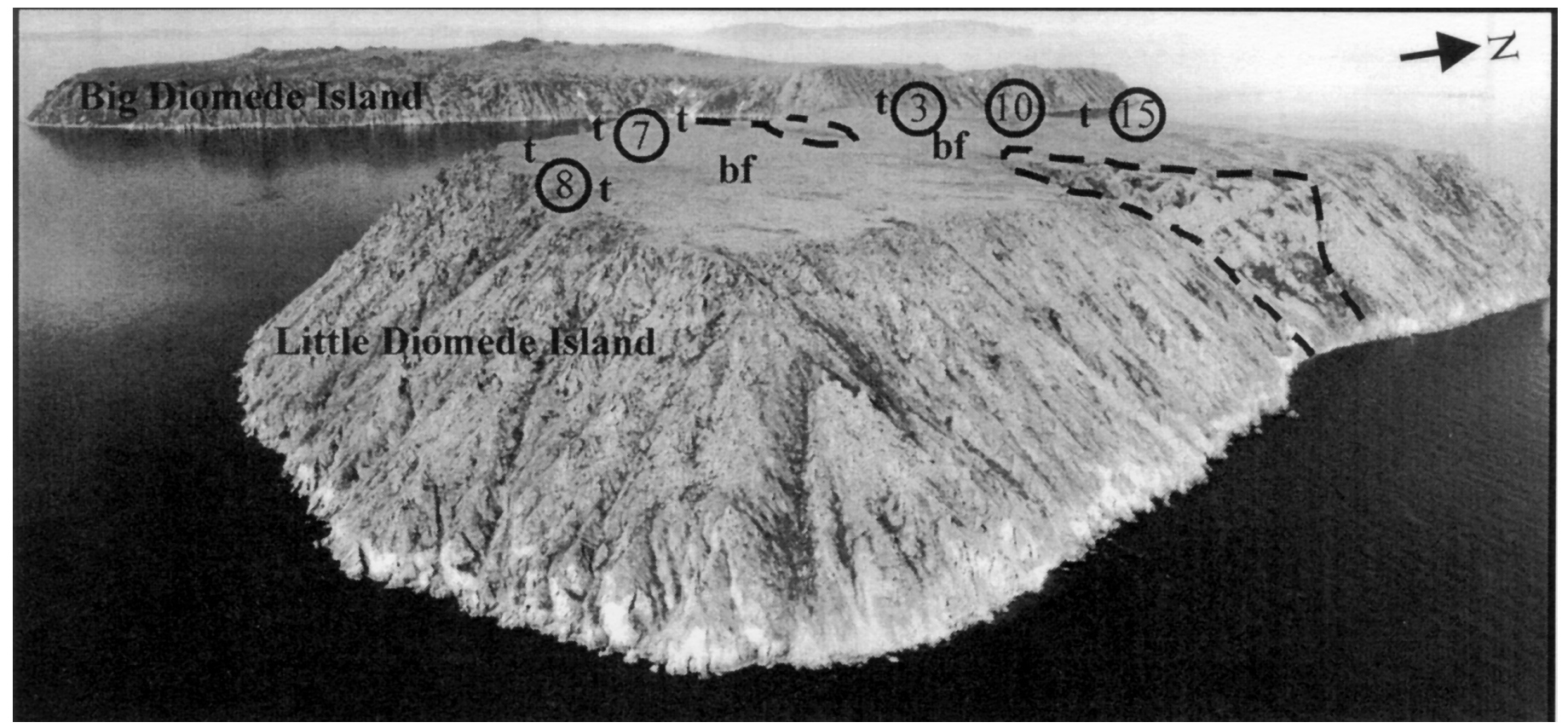

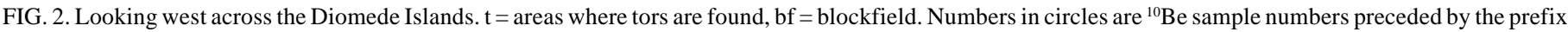

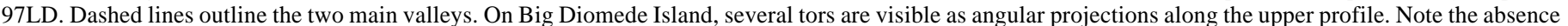
of shorelines or marine sediment on the cliffsides of the island. Air photograph provided by AeroMap U.S.

\section{GEOLOGY OF THE BERING SEA AND BERING STRAIT REGION}

The northern Bering Sea is a shallow, epicontinental sea (45\% of the area is less than $200 \mathrm{~m}$ deep; Nelson et al., 1974; Sharma, 1974; Nelson, 1982). It has been separated from the Pacific Ocean by the Aleutian Islands since the late Eocene, when the Aleutian arc-trench subduction zone formed (Nelson et al., 1974; Worall, 1991). Subsequently, right lateral strike slip faults evolved parallel to the Beringian Active Margin; today these faults extend from the Sea of Okhotsk to southern Alaska (Worall, 1991). During a southward shift in the subduction zone, the Kula plate, of which the Bering Sea is a remnant, became incorporated into the North American-Siberian plate (Nelson et al., 1974). Movement of strike slip faults to the north and south of the Bering Strait determined its physiography, and played a crucial role in the intercontinental land connections between modern Asia and North America (Nelson et al., 1974). The Bering Strait Fault Zone, $38 \mathrm{~km}$ south of Little Diomede Island, trends westeast from the Bering Strait to Grantley Harbor (Fig. 1; Plafker et al., 1993).

In a study of marine sediments, Grim and McManus (1970) interpreted the surface sediments west of $169^{\circ} \mathrm{W}$ as glacial and marine in origin, whereas they interpreted the surface sediments east of $169^{\circ} \mathrm{W}$ to be underlain by river deposits. Glacial deposits have also been interpreted in the west part of the Chirikov Basin by Hess (1985). Grim and McManus (1970) also identified a ridge $75 \mathrm{~km}$ offshore, roughly paralleling Chukotka for $130 \mathrm{~km}$, which is buried 30-40 m below the seafloor (Fig. 1). Boulders recovered in dredge hauls $9 \mathrm{~km}$ north of St. Lawrence Island suggest that the feature is a glacial moraine. This moraine is interpreted as Marine Isotope Stage (MIS) 8 in age (Krestaage, Russian terminology, D.M. Hopkins, pers. comm. 1997, Fig. 3). Toward its northern end, the moraine is defined by a belt of widely spaced chaotic seismic reflectors (possibly erratics), also interpreted to be glacial in origin (D.M. Hopkins, pers. comm. 1997). Although the inferred moraine ridge extends $150 \mathrm{~km}$ to the NNE from St. Lawrence Island, it terminates $50-100 \mathrm{~km}$ south of Little Diomede Island.

Tectonic activity in the Bering Strait since the late Tertiary/early Quaternary is indicated by deformed scarps, raised shorelines, and marine terraces in the York Mountains (Fig. 1) and offshore of Seward Peninsula (Grim and McManus, 1970; Kaufman and Hopkins, 1986). Differential uplift rates are estimated to be $5 \mathrm{~m} / \mathrm{km}$ along the Port Clarence Fault Zone (Fig. 1; Sainsbury, 1967a).

\section{The York Terrace}

Numerous high sea level events ranging in age from late Pliocene to recent are recognized in western Alaska (Fig. 3; Hopkins, 1967; Kaufman, 1992; Kaufman and BrighamGrette, 1993). The ages of the events are determined by stratigraphic relationships, distinctive molluscan faunas, position in geomagnetic polarity-reversal sequences, radiometric dating, and amino acid geochronology.

The York terrace is a 2.6 million-year-old marine surface, which represents a sea level stand $3060 \mathrm{~m}$ higher than the present level in the Bering Strait. The terrace is a prominent, continuous surface that can be traced for $30 \mathrm{~km}$ 


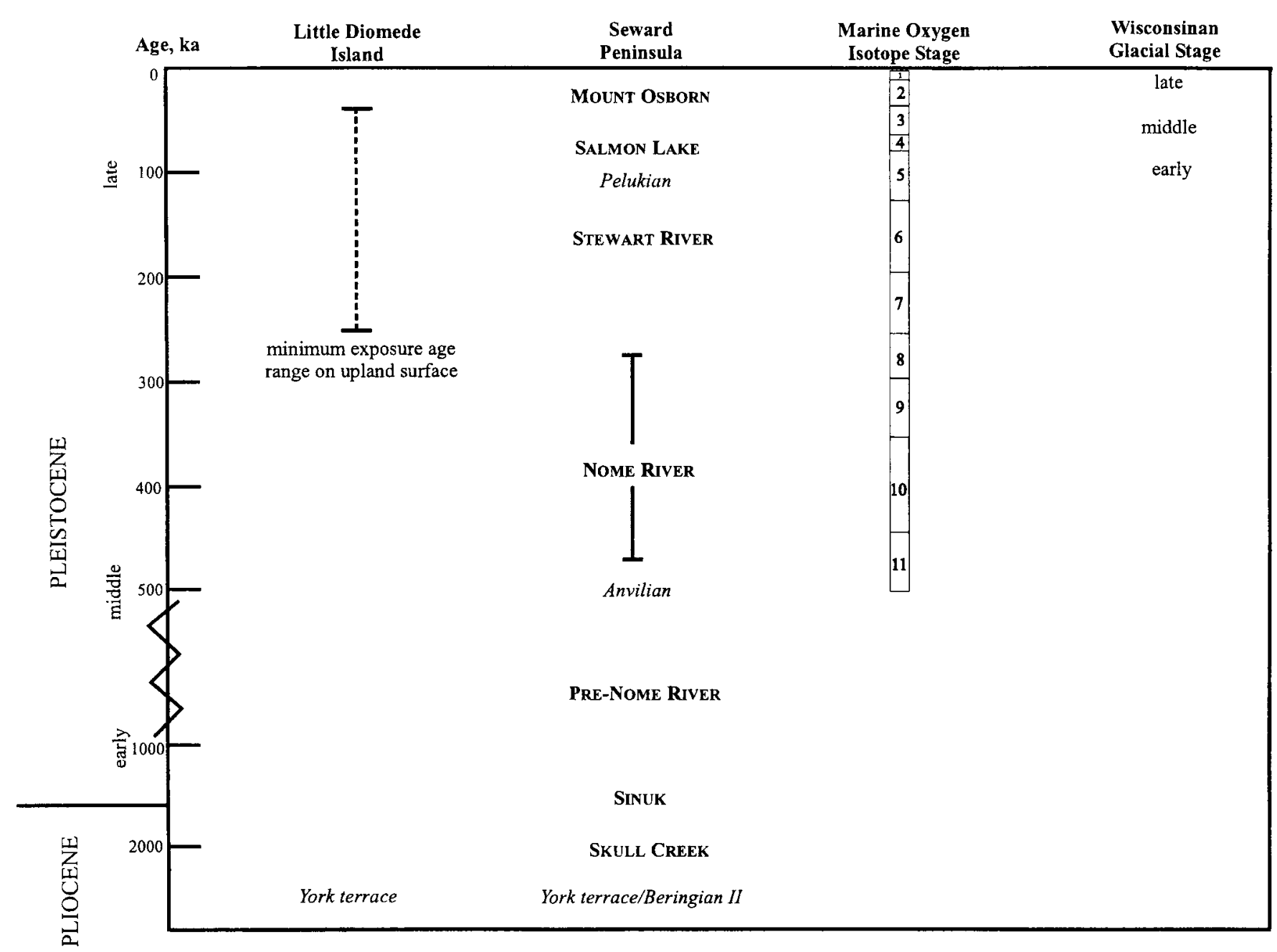

FIG. 3. Correlation of glacial and marine events on Little Diomede Island and Seward Peninsula. Glaciations in small capitals and sea level transgressions in italics. Note break in age scale.

along the southern front of the York Mountains (Sainsbury, 1967a; Brigham-Grette and Hopkins, 1994). It was originally dated at $2.6 \mathrm{Ma}$ by mollusk faunas in marine conglomerate (Sainsbury, 1967a), and recent studies have confirmed the age on the basis of paleomagnetic data and the presence of the extinct mollusk Fortipecten hallae, a last appearance datum for this species in the region (Brigham-Grette and Hopkins, 1994). Amino acid analysis on Mya and Hiatella found in association with Fortipecten hallae from the California River valley and Nome support a correlation between the York terrace and the Beringian II marine transgression described in western Alaska (Kaufman and Brigham-Grette, 1993; BrighamGrette and Hopkins, 1994). Subsequent tectonic activity during the mid Pleistocene uplifted the 30-60 m shoreline an additional $155-185 \mathrm{~m}$ along the south front of the York Mountains. The resulting altitude of the York terrace is $156 \mathrm{~m}$ on Cape Mountain and up to $225 \mathrm{~m}$ west of Lost River (Fig. 1; Sainsbury, 1967b). The extent of the uplift that deformed this shoreline in the Bering Strait was unknown before the present study, although it is critical to the Pliocene/early Pleistocene paleogeography of the
Bering Strait. If the York terrace is projected $43 \mathrm{~km}$ west of Cape Mountain to Little Diomede Island using Sainsbury's (1967a) $5 \mathrm{~m} / \mathrm{km}$ uplift rate, the elevation of the York terrace would be $371 \mathrm{~m}$.

\section{Regional Glacial History}

In the absence of detailed studies on Little Diomede Island, the glacial history is discussed in the context of regional studies.

St. Lawrence Island: Holmes and Thor (1982) proposed an eastern limit for Chukotka Ice of unknown age extending onto St. Lawrence and King Islands (Fig. 1). Supportive evidence includes glaciotectonic folds and faults in sediment on the northwest corner of St. Lawrence Island and amino acid geochronology on mollusks incorporated into glacial deposits on the island (Hopkins et al., 1972; Benson, 1993, 1994). Recent studies have shown that ice advanced twice onto the island. The first advance occurred just after the mid Pleistocene (MIS 11) Anvilian marine transgression (Ivanov, 1986; Brigham-Grette et al., 1992). During MIS 5, small cirque glaciers formed at 
$155 \mathrm{~m}$ on St. Lawrence Island, after which, during late MIS 5 or MIS 4, ice from Chukotka is proposed to have advanced eastward onto the island (Heiser, 1997; BrighamGrette et al., 2001). Projected snowlines for the late Wisconsinan (MIS 2) on St. Lawrence Island are $150 \mathrm{~m}$ in altitude, rising to $300-450 \mathrm{~m}$ in the Bering Strait (Heiser, 1997).

St. George and Aleutian Islands: Frost-shattered roches moutonnées, faceted and striated boulders, stratified drift, striae, and till indicate that a small ice cap and 2-4 cirque glaciers existed on St. George Island (Hopkins and Einarsson, 1966). Although there is no absolute age control for this glaciation, relative weathering criteria suggest it is correlative with the Nome River glaciation on Seward Peninsula, considered to be mid Pleistocene in age (Hopkins and Einarsson, 1966; Kaufman and Hopkins, 1986). Mid Pleistocene tills are also recognized on some of the Aleutian Islands (Thorson and Hamilton, 1986).

Seward Peninsula: Seven main glacial advances are recognized on Seward Peninsula (Figs. 1 and 3; Sainsbury, 1967b; Kaufman and Hopkins, 1986). The three earliest glaciations are discussed below. The pre-Nome River Drift (early to mid Pleistocene) is delineated by isolated erratics and extensive drift blankets on which little primary glacial relief is preserved. Evidence for the Sinuk glaciation (pre-Pleistocene to early Pleistocene) includes smooth moraine ridges south of the York Mountains at the mouths of the Kanauguk, King, and Lost Rivers, as well as till on the peninsula extending into northeast Lopp Lagoon (Fig. 1). The presence of tors on bedrock slopes on western Seward Peninsula originally suggested that the upland surfaces were glaciated only during the Sinuk interval; however, it has been demonstrated that tors can be preserved under cold-based as well as late Wisconsinan ice sheets (Sugden and Watts, 1977). The Sinuk glaciation moraine ridges extend $7 \mathrm{~km}$ offshore at Nome. The Skull Creek glaciation (pre-Pleistocene) is recognized by scattered erratics on low bedrock hilltops near Skull Creek and in the valley of the California River (Fig. 1), as well as by ice-rounded topography on hills between the western end of the York Mountains and Cape Mountain (Sainsbury, 1967b). The distribution of limestone drift at the northwestern end of the York Mountains suggests that an early Wisconsinan ice sheet occupied lowlands of the southernmost Chukchi Sea and Bering Strait area (Sainsbury, 1967a).

Bering Strait: A large portion of the research on past glaciation in the Bering Strait has been theoretical (Grosswald, 1988, 1998; Hughes and Hughes, 1994; Grosswald and Hughes, 1995). Grosswald (1998) proposed that sometime during the Pleistocene a marinebased ice sheet was centered over the East Siberian Sea, extending southward into the Bering Strait. According to this model, Little Diomede Island would have been covered by $1000-1500 \mathrm{~m}$ of ice. Sher (1995) and investigations by others using SAR imagery (Heiser, 1997), field-based mapping and numerical dating techniques
(Gualtieri et al., 2000), and amino acid analyses on fossil mollusks from glaciomarine deposits (Brigham-Grette et al., 2001) indicate that this model is unsubstantiated.

\section{METHODOLOGY}

In July 1997, we investigated the perimeter of Little Diomede Island by boat and traversed the island's upland surface on foot. Five samples of granite from the upland surface were dated using ${ }^{10} \mathrm{Be}$ cosmogenic isotope analysis, a surface exposure dating technique (Fig. 2, Table 1). The premise of cosmogenic isotope surface exposure dating is that buildup and accumulation of cosmogenic isotopes begins once a rock is exposed at or near the surface. Using Accelerator Mass Spectrometry (AMS), the isotopic ratio of the cosmogenically produced isotope (in this case ${ }^{10} \mathrm{Be}$ ) to the stable isotope (in this case ${ }^{9} \mathrm{Be}$ ) is determined. The ratio is then multiplied by the concentration of the stable isotope in the sample, which is known from the mass and concentration of the Be spike added to the sample. Knowing the half-life of ${ }^{10} \mathrm{Be}(1.5 \mathrm{Ma})$, one can determine the length of time that the rock has been exposed at the surface (i.e., exposure age). For details regarding the use of cosmogenic isotopes as a surface exposure dating technique, see papers by Davis and Schaeffer (1955), Phillips et al. (1986), Lal (1991), Zreda et al. (1991), Nishiizumi et al. (1993), Kurz and Brook (1994), Zreda and Phillips (1994), Bierman et al. (1995), Clark et al. (1995), Gosse et al. (1996), and Bard (1997).

Five dated samples were taken by means of a hammer and chisel from the edge of bedrock outcrops. Sample locations are shown in Figure 2. Sample 97LD3, a slab $4 \mathrm{~cm}$ thick, was taken from the top of a granite outcrop ( $3 \mathrm{~m}$ long, $2 \mathrm{~m}$ wide, $15 \mathrm{~m}$ high) dipping $12^{\circ}$ on the northwest side of the island. Sample 97LD7, a slab $7 \mathrm{~cm}$ thick, was taken from the uppermost surface of a tor dipping $32^{\circ}$ on the southwest side of the island. The tor is $10 \mathrm{~m} \mathrm{long}$, $4 \mathrm{~m}$ wide, and $7 \mathrm{~m}$ high. Sample 97LD8, a slab $5 \mathrm{~cm}$ thick, was taken from the horizontal uppermost surface of an outcrop at the southern end of the island. Sample 97LD10, a slab $5 \mathrm{~cm}$ thick, was taken from an overhanging surface dipping $30^{\circ}$ on an outcrop at the northern end of the island. Sample 97LD15, a slab $4.5 \mathrm{~cm}$ thick, was taken from a horizontal tor surface $3 \mathrm{~m}$ below the uppermost surface of the northern end of the island (Fig. 5).

Rocks were first cleaned using a wire brush to remove lichens. Samples were crushed, and the 500-250 mm size fraction was sieved off and then subjected to chemical pretreatment. Samples were cleaned with water and passed through a hand magnet to remove iron and other magnetic particles acquired during the crushing process. The final step in the physical sample preparation was to isolate the quartz. Quartz is used as the target mineral because it has the simplest target chemistry; it is also ubiquitous and chemically resistant. In addition, the use of quartz allows rigorous acid leaching to remove surface contamination 
TABLE 1. Beryllium-10 exposure ages. AMS measurements were made on quartz from granite. Exposure ages are given for erosion rates of 0 and $10 \mathrm{~mm} / \mathrm{ka}$. Ages were calculated using PRIME Lab's RICH computer program.

\begin{tabular}{lrrc}
\hline \hline Sample & NR/S & $\begin{array}{c}\text { no erosion } \\
\text { RICH Age }\end{array}$ & $\begin{array}{c}10 \mathrm{~mm} / \mathrm{ka} \\
\text { RICH Age }^{2}\end{array}$ \\
\hline 97LD3 blockfield & $69 \pm 9$ & $41 \pm 6$ & $66 \pm 17$ \\
97LD7 tor & $155 \pm 29$ & $141.8 \pm 28$ & $254^{3}$ \\
97LD8 blockfield & $102 \pm 17$ & $80 \pm 14$ & $143^{3}$ \\
97LD10 blockfield & $37 \pm 11$ & $28 \pm 8$ & $36 \pm 15$ \\
97LD15 tor & $69 \pm 11$ & $47 \pm 8$ & $84 \pm 31$ \\
\hline \hline
\end{tabular}

${ }^{1} \mathrm{NR} / \mathrm{S}=$ The normalized radionuclide/stable nuclide ratio and reported absolute error. Units are in E-15. Errors on NR/S ratios and ages are limited by precision of AMS measurements at PRIME Lab. Production rate was corrected for latitude of $65^{\circ} \mathrm{N}$ and an altitude of $363 \mathrm{~m}$.

${ }^{2}$ Ages are in thousands of years. No shielding corrections were required for any samples.

${ }^{3}$ Extrapolation using an increase in "no erosion age" of $79 \%$.

and atmospherically produced ${ }^{10} \mathrm{Be}$. The quartz and other felsic minerals were separated using a $\mathrm{Carpco}^{\mathrm{TM}}$ Dry High-Intensity Induced-Roll Magnetic Separator.

After separation, the samples were etched with phosphoric acid two or three times, or until all other minerals (mostly feldspars) had been removed and only quartz remained. The "clean" quartz was then sent to Chemistry Operations at PRIME Lab (Purdue University) for the remainder of the chemical preparation. Complete chemical preparation procedures can be obtained from Purdue University's PRIME Lab Chemistry Operations Worksheets AW0010 and AW0011 (PRIME Lab, 1995). The chemical sample preparation involves leaching the quartz with hydrofluoric and nitric acid. AMS target preparation begins with adding a $\mathrm{Be}$ spike to the sample by producing a Be carrier. This step is followed by evaporation of the quartz, cation separation, cation purification, oxidation, and packing.

\section{SURFICIAL GEOLOGY OF LITTLE DIOMEDE ISLAND}

The modern upland surface of Little Diomede Island is a 350-363 m high frost-shattered surface sloping to the northeast with tors along its west and south sides (Fig. 2). The upland may be classified as a cryoplanation surface: a land surface reduced to low relief by processes associated with intensive frost action, supplemented by the actions of running water, moving ice, and other agents (Bates and Jackson, 1983; Allaby and Allaby, 1991). Reger and Péwé (1976) classify cryoplanation surfaces as bedrock steps or terraces on ridge crests and hilltops, chiefly occurring in nonglaciated areas near the general altitude of the snowline. Cryoplanation terraces are widespread on the uplands in nonglaciated portions of central Alaska, including the western tip of Seward Peninsula (Reger and Péwé, 1976).
Reger and Péwé (1976) suggest formation of the surfaces is largely due to scarp retreat as the result of nivation.

\section{Drainage Channels}

The upper surface of the island supports one main valley on its east side (Fig. 2) and a smaller valley on its west side (Fig. 2). The remaining steep sides of the island are notched by small channels that drain small areas of the upland surface (Fig. 2). The larger eastern valley is approximately $75 \mathrm{~m}$ wide and can be traced from the eastern rim of the island to sea level. Drainage through the channel feeding the valley is ephemeral.

Visible from oblique air photographs are two former drainage channels cut into bedrock and oriented east-west. Solifluction lobes, consisting of weathered material, define a radial drainage pattern also visible from air photographs.

\section{Blockfield}

The blockfield is a transitional area between the eastside valley and the outer rim of tors and slabs of frostshattered granite (Fig. 2). The blockfield is composed of coarse, angular granite blocks, up to $4 \mathrm{~m}$ in diameter. Some of the boulders are perched on smaller rocks (Fig. 4). It appears that the boulders in low spots have been frostheaved to the surface, while most others close to the outer rim of the island have been frost-shattered or cracked in situ. The surface is similar in morphology to the "stone runs" and up-ended slabs of quartzite in the Falkland Islands as described by Clapperton (1993).

\section{Tors}

The morphology of some tors on the north and west outer rims of the upland surface resemble roches moutonnées (Fig. 5); however, striations or polished surfaces, if present in the past, are not preserved in the frostshattered granite. The lee sides of these tors face west, implying that they were the product of glacial erosion from ice flowing from the east; however, there is no further evidence to support ice from the east (mainland Alaska) flowing onto Little Diomede Island. Alternatively, the form of the tors may be related to jointing patterns in the local bedrock.

\section{Large and Small-Scale Weathering}

Observations regarding the extent of differential weathering are especially important for interpreting cosmogenic isotope ages. Evidence for large-scale weathering includes blocks, some as large as $5 \mathrm{~m}$ in diameter, that have been heaved apart or broken at right angles to the outcrop. On the north side of the island, alongside the footpath to the upland surface, is a granite outcrop that displays at least $60 \mathrm{~cm}$ of onionskin exfoliation. In areas on the top of the island, it is also common to see sheets of granite $5 \mathrm{~cm}$ thick 

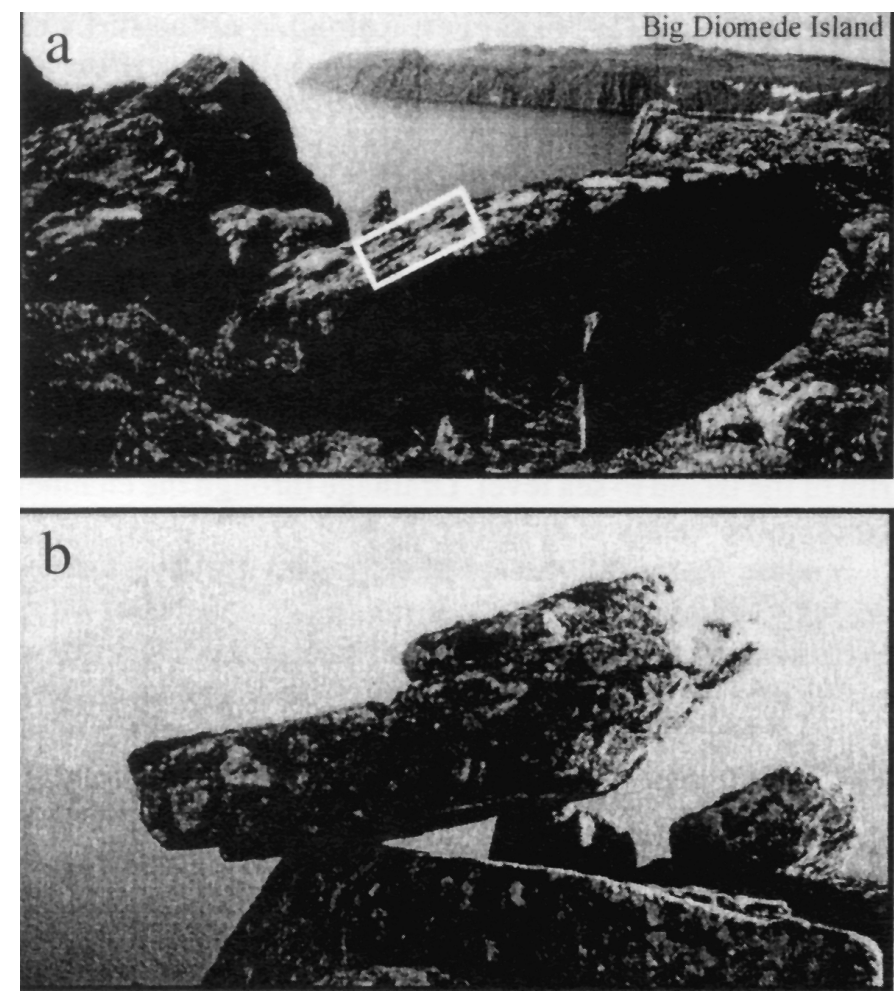

FIG. 4. a) Perched boulder on north side of the island (hammer in white rectangle indicates scale); b) Perched boulder on north side of the upper plateau $\sim 350 \mathrm{~m}$. Boulder is approximately $3 \mathrm{~m}$ in length.

being broken apart from outcrops. Evidence for smallscale weathering includes exposed feldspar crystals and quartz veins standing up to $10 \mathrm{~mm}$ above the surrounding matrix. Granular disintegration in granite, producing hollows $5 \mathrm{~cm}$ deep, is also observed on flat-topped blocks on the north and west rims. Moss, which is $10 \mathrm{~cm}$ thick on some rocks, is present to trap water and facilitate mechanical erosion.

\section{DISCUSSION OF THE AGE AND ORIGIN OF THE UPLAND SURFACE}

The exposure age of the upland surface on Little Diomede Island, determined by ${ }^{10} \mathrm{Be}$ cosmogenic isotope dating, ranges from 36 to $254 \mathrm{ka}$ (Table 1). Our hypothesis is that the island's upland surface evolved in two stages: 1) a late Pliocene marine planation followed by tectonic uplift and 2 ) a period of periglacial activity.

\section{Cosmogenic Isotope Dates and Reasons for Age Distribution}

It is difficult to assess the exact age of the upland surface because of variability within the cosmogenic isotope ages. Disparate ages result from a combination of analytical errors (associated with the chemical sample preparation and the accelerator mass spectrometry measurements at PRIME Lab) and geologic factors (such as

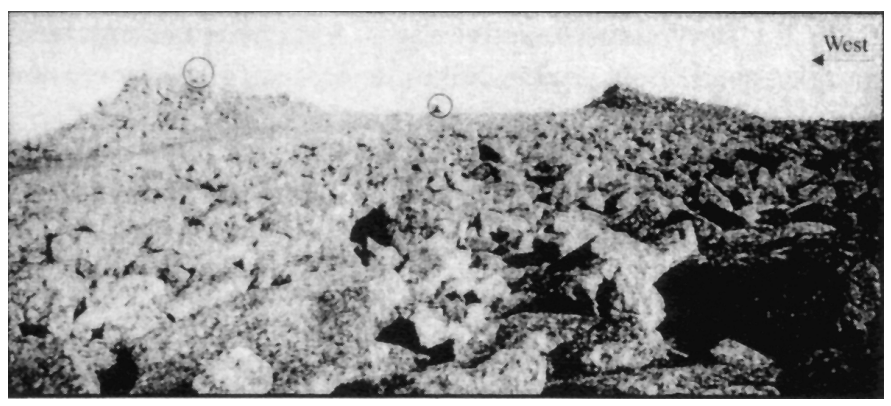

FIG. 5. Looking north at two roche moutonnée-shaped granite tors on the north rim of the island. The ${ }^{10} \mathrm{Be}$ cosmogenic isotope age on the westernmost tor assuming an erosion rate of $10 \mathrm{~mm} / \mathrm{ka}$ is $84 \pm 31 \mathrm{ka}$. There are two satellite dishes for scale (circled).

differential weathering and the dip of the sampled surface). However, because of weathering and possible underestimation of the production rate of ${ }^{10} \mathrm{Be}$, the dates are interpreted to be minimum ages. Since both large- and small-scale weathering features are present in the granite, it is difficult to assess how much rock has been removed by weathering and erosion since the rock surfaces were first exposed. Therefore, the ages are interpreted to be minimum exposure age estimates.

A range of ages is given using a "no erosion" model and a " $10 \mathrm{~mm} / \mathrm{ka}$ " erosion model (Table 1). An erosion rate of $10 \mathrm{~mm} / \mathrm{ka}$ was chosen on the basis of the maximum relief of quartz veins $(10 \mathrm{~mm})$ on the sampled surfaces, which provides evidence that at least $10 \mathrm{~mm}$ of erosion has taken place. It was not possible to calculate a $10 \mathrm{~mm} / \mathrm{ka}$ erosion rate for older samples (more than $80 \mathrm{ka}$ old) because of limitations in RICH, PRIME Lab's age calculation program. However, if the same percentage increase (79\%) as that of the next oldest sample (97LD15, $47 \pm 8 \mathrm{ka}$ ) is used to calculate a " $10 \mathrm{~mm} / \mathrm{ka}$ " erosion rate for samples 97LD8 (older than $80 \mathrm{ka}$ ) and 97LD7 (older than $142 \mathrm{ka}$ ), their ages become 143 and $254 \mathrm{ka}$, respectively (Table 1). Using this extrapolation, the " $10 \mathrm{~mm} / \mathrm{ka}$ " erosion model ages range from 36 to $254 \mathrm{ka}$. The "no erosion" ages are unrealistic, since signs of weathering are ubiquitous on the rocks; therefore, the range of ages of the five samples assuming $10 \mathrm{~mm} / \mathrm{ka}$ erosion $(36-254 \mathrm{ka})$ is used for interpretation.

\section{Stage I (Late Pliocene/Early Pleistocene) - Marine}

As the elevation of the upland surface of Little Diomede Island is $363 \mathrm{~m}$, the hypothesis that the upland surface of Little Diomede Island is an extension of the York terrace is supported by uplift rates and regional-scale geomorphology. The planar upland surface of Little Diomede Island is probably best interpreted as a former marine wave-cut platform. If the York terrace was uplifted 2.6 million years ago and has been eroding at the rate of $10 \mathrm{~mm} / \mathrm{ka}$, then it has undergone a total of $26 \mathrm{~m}$ of erosion. As was noted earlier, the projected elevation of the York terrace on Little Diomede Island is $371 \mathrm{~m}$; however, after $26 \mathrm{~m}$ of erosion this would be reduced to $345 \mathrm{~m}$, which is close to the present elevation (350-363 m) of the upper 
surface of the island. Using Sainsbury's (1967a) uplift rates, we conclude that this surface may be a remnant of the 2.6 million-year-old York terrace in the Bering Strait. However, it is also possible that there are numerous other terraces between the York terrace and the Lost River terrace and that the Little Diomede upland represents one of these intermediate high sea level stands (T. Hudson, pers. comm. 1998). The correlation is based on geomorphology, projected uplift rates, and assumed erosion rates. Note that the rounded pebbles or beach shingle common on other raised marine surfaces in the Arctic are not found on the upland surface of Little Diomede Island.

\section{Stage II (Late Pleistocene to Present) - Periglacial}

Subsequent to marine planation, the Little Diomede Island plateau has likely been dominated by periglacial weathering processes for at least $36 \mathrm{ka}$ (since MIS 3) and possibly $254 \mathrm{ka}$ (since MIS 7/8). Evidence for subaerial erosion throughout the Pleistocene on the exposed Bering shelf has also been recognized (Grim and McManus, 1970). Evidence for the periglacial environment on Little Diomede Island includes the cryoplanation surface, the blockfield, and the tors. The length of time required for blockfields to form varies with rock type and climate, but within the Bering Strait, this process may be accelerated by high amounts of precipitation, fog, frost action, and salt weathering (Embleton and King, 1975).

\section{The Possibility of Glaciation?}

Although there is no direct evidence for glaciation of Little Diomede Island, it is possible that perennial snowbanks or even a small plateau ice cap existed on the island during the early Pleistocene. In support of glaciation of the island are the valleys on the east and west sides, which may be remnants of former drainage, as well as the perched boulders (Fig. 4), which could be interpreted as glacially deposited. The early Pleistocene snowline dropped to $150 \mathrm{~m}$ on St. George Island, south of Little Diomede Island, and it was probably lower than $200-250 \mathrm{~m}$ on Seward Peninsula (Hopkins and Einarsson, 1966; Kaufman and Hopkins, 1986). On the basis of estimated snowline elevation alone, Little Diomede Island fits into the regional pattern of westward sloping paleosnowline altitudes reconstructed for the Bering Strait and the York Mountains during the late Pleistocene. Offshore seismic evidence and field observations on Little Diomede Island (i.e., no erratics found on the island, west-facing lee side tors) indicate it is unlikely that ice from Chukotka actually reached the island.

\section{CONCLUSIONS}

On the basis of geomorphology and the projection of uplift rates, we hypothesize that the flattened top of the upland surface of Little Diomede Island is a former marine terrace correlative with the 2.6 million-year-old York terrace on Seward Peninsula. After marine planation, Little Diomede Island developed a cryoplanation surface because of intense periglacial weathering at least since MIS 3 and possibly since MIS 7/8 (Fig. 3). More cosmogenic isotope dating on tors and the blockfield from the upland surface of Little Diomede Island and an investigation of the surficial geology of Big Diomede Island are needed to further constrain the age of the two stages. The implications for this research are the following:

1. If the recognition and projection of the York terrace in the Bering Strait is correct, this evidence helps to constrain early Pleistocene uplift rates and regional warping in the Bering Sea.

2. Evidence indicates that the upland surface of Little Diomede Island has remained a periglacial environment for at least $36 \mathrm{ka}$; therefore, it was not covered by ice due to extensive glaciation. Thus this work adds to the continuum of research substantiating restricted ice cover and modest sea level fluctuations in the Bering Strait region since the late Pleistocene.

\section{ACKNOWLEDGEMENTS}

The Arctic Institute of North America and the Department of Geosciences, University of Massachusetts, financially supported this research. AeroMap U.S. provided air photographs of the island. Permission to work on Little Diomede Island was granted by the Bering Straits Native Corporation, Inalik Native Corporation, and Indian Reorganization Act, and the National Park Service. Dale Taylor (National Park Service) and Sue Steinacher (Bureau of Land Management) helped with field season planning and logistics. Helicopter support was provided by Erik Pentilla of Evergreen Helicopter, and accommodation on the island was made possible by Opik, Laney, Dora and Phillip Ahkinga. We also want to acknowledge and thank the community of Inalik for showing interest in our research and helping with logistics. Rock samples for ${ }^{10} \mathrm{Be}$ cosmogenic isotope analysis were chemically prepared and isotopes were measured by means of AMS at PRIME Lab, Purdue University. Ages were calculated using PRIME Lab's RICH computer program. The current version of this program can be found on the World Wide Web athttp://primelab.physics.purdue.edu/ diskf/anonymous/www/primelab/guide.txt.

This research and the ideas presented here grew and were improved upon following discussions with Dwayne Anderson, Donald J. Grybeck (U.S. Geological Survey-Anchorage), Thomas D. Hamilton (U.S. Geological Survey-Anchorage), David M. Hopkins (University of Alaska), Travis Hudson (American Geological Institute) and Hans C. Nelson (U.S. Geological SurveyMenlo Park). Formal reviews by Wes Blake Jr., Nel Caine, and Rod Smith greatly improved this paper. 


\section{REFERENCES}

ALASKA DEPARTMENT OF COMMUNITY \& ECONOMIC DEVELOPMENT. 1998. Research and Analysis Section. http:/ /www.dced.state.ak.us/mra/CF_CIS.htm

ALLABY, A., and ALLABY, M. 1991. The concise Oxford dictionary of earth sciences. New York: Oxford University Press.

BARD, E. 1997. Nuclide production by cosmic rays during the last Ice Age. Science 277:532-533.

BARKER, F., MILLER, T.P., and GEHRELS, G.E. 1994. Plate 13. Major occurrences of accreted volcanic rocks and pre-Cenozoic and some early Tertiary plutonic rocks of Alaska. In: Plafker, G., and Berg, H.C., eds. Geology of Alaska. Geology of North America (GNA-1). Geological Society of America, 1 sheet, scale 1: 2500000 .

BATES, R.L., and JACKSON, J.A. 1983. Dictionary of geological terms. 3rd ed. New York: Doubleday.

BENSON, S. 1993. Glacially deformed sediments of Lavrentiya Bay, Chukotka Peninsula, Far Eastern Russia, and the north shore of St. Lawrence Island, Alaska. In: Aber, J.S., ed. Glaciotectonics and mapping glacial deposits. Proceedings of the INQUA Commission on Formation and Properties of Glacial Deposits. Canadian Plains Research Center. University of Regina. 1-8 and plates 1-4.

. 1994. Pleistocene stratigraphy and ice extent across central Beringia. Unpublished M.Sc. thesis, Department of Geosciences, University of Massachusetts.

BIERMAN, P., GILLESPIE, A., CAFFEE, M., and ELMORE, D. 1995. Estimating erosion rates and exposure ages with ${ }^{36} \mathrm{Cl}$ produced by neutron activation. Geochimica et Cosmochimica 59:3779-3798.

BRIGHAM-GRETTE, J., and HOPKINS, D.M. 1994. The significance of Fortipecten hallae in the correlation of Pliocene high sea levels in the Bering Strait region. American Quaternary Association Program with Abstracts of the 13th Biennial Meeting. University of Minnesota. 202.

BRIGHAM-GRETTE, J., BENSON, S., HOPKINS, D., HEISER, P., IVANOV, V., and BASILYAN, A. 1992. Middle and late Pleistocene Russian glacial ice extent in the Bering Strait region: Results of recent fieldwork. GSA Abstracts with Programs: A346.

BRIGHAM-GRETTE, J., HOPKINS, D.M., IVANOV, V.F., BASILYAN, A., BENSON, S.L., HEISER, P.A., and PUSHKAR, V.S. 2001. Last interglacial (Isotopte Stage 5) glacial and sea level history of coastal Chukotka Peninsula and St. Lawrence Island, western Beringia. Quaternary Science Reviews 20(1-3):419-436.

BROWN, J., FERRIANS, O.J., Jr., HEGINBOTTOM, J.A., and MELNIKOV, E.S. 1997. Circum-Arctic map of permafrost and ground-ice conditions. Circum-Pacific Map Series. Map CP-45. U.S. Geological Survey, 1 sheet, scale 1:10000000.

CLAPPERTON, C. 1993. Quaternary geocryogenic features of South America and the Falkland Islands (Islas Malvinas). In: Clapperton, C., ed. Quaternary geology and geomorphology of South America. New York: Elsevier Press. 521-561.
CLARK, D., BIERMAN, P., and LARSEN, P. 1995. Improving in situ cosmogenic chronometers. Quaternary Research 44: 367-377.

DAVIS, R., Jr., and SCHAEFFER, O.A. 1955. Chlorine-36 in nature. Annals of the New York Academy of Science 62: $105-122$.

EMBLETON, C., and KING, C.A.M. 1975. Periglacial geomorphology. New York: John Wiley and Sons.

GOSSE, J.C., REEDY, R., HARRINGTON, C.D., POTHS, J., and GILLESPIE, A.R. 1996. Terrestrial cosmogenic nuclide dating: Tested and ready for action. EOS 77:275-276.

GREBMEIER, J., SMITH, W.O., and CONOVER, R.J. 1995. Biological processes on Arctic continental shelves: Ice-oceanbiotic interactions. In: Smith, W.O., and Grebmeier, J.M., eds. Arctic oceanography: Marginal ice zones and continental shelves. Washington, D.C.: American Geophysical Union. 231-261.

GRIM, M.S., and McMANUS, D.A. 1970. A shallow seismicprofiling survey of the northern Bering Sea. Marine Geology 8:293-320.

GROSSWALD, M.G. 1988. An Antarctic-style ice sheet in the Northern Hemisphere: Towards new global glacial theory. Polar Geography and Geology 12:239-267.

- 1998. Late-Weichselian ice sheets in Arctic and Pacific Siberia. Quaternary International 45/46:3-18.

GROSSWALD, M.G., and HUGHES, T.J. 1995. Paleoglaciology's grand unsolved problem. Journal of Glaciology 41:313-332.

GUALTIERI, L., GLUSHKOVA, O.Y., and BRIGHAM-GRETTE, J. 2000. Evidence for restricted ice extent during the last glacial maximum in the Koryak Mountains of Chukotka, Far Eastern Russia. Geological Society of America Bulletin 112(7): $1106-1118$.

HEISER, P. 1997. Extent, timing, and paleogeographic significance of multiple Pleistocene glaciations in the Bering Strait region. Unpublished Ph.D. thesis, Department of Geology and Geophysics, University of Alaska.

HESS, G.D. 1985. Quaternary stratigraphy and sedimentation: Northern Bering Sea, Alaska. Unpublished Ph.D. thesis, Department of Geology, Stanford University.

HOLMES, M.L., and THOR, D.R. 1982. Distribution of gascharged sediment in Norton Sound and Chirikov basin, northeastern Bering Sea. Geologie en Mijnbouw 61:79-89.

HOPKINS, D. 1967. Quaternary marine transgressions in Alaska. In: Hopkins, D.M., ed. The Bering land bridge. Stanford: Stanford University Press. 47-90.

HOPKINS, D., and EINARSSON, T. 1966. Pleistocene glaciation on St. George, Pribilof Islands. Science 152:343-345.

HOPKINS, D.M., ROWLAND, R.W., and PATTON, W.W. 1972. Middle Pleistocene mollusks from St. Lawrence Island and their significance for the paleoceanography of the Bering Sea. Quaternary Research 2:119-134.

HUGHES, B.A., and HUGHES, T.J. 1994. Transgressions: Rethinking Beringian glaciation. Palaeogeography, Palaeoclimatology, Palaeoecology 110:275-294.

IVANOV, V. 1986.Quaternary deposits of coastal eastern Chukotka [In Russian]. Vladivostok: Russian National Academy of Sciences. 
JENNESS, D. 1929. Little Diomede Island, Bering Strait. Geographical Review 19:78-86.

KAUFMAN, D.S. 1992. Aminostratigraphy of Pliocene-Pleistocene high sea level deposits, Nome coastal plain and adjacent nearshore area, Alaska. Geological Society of America Bulletin 104(1): 40-52.

KAUFMAN, D.S., and BRIGHAM-GRETTE, J. 1993. Aminostratigraphic correlations and paleotemperature implications, Pliocene-Pleistocene high sea level deposits, northwestern Alaska. Quaternary Science Reviews 12:21-33.

KAUFMAN, D.S., and HOPKINS, D.M. 1986. Glacial history of the Seward Peninsula. In: Hamilton, T.D., Reed, K.M., and Thorson, R.M., eds. Glaciation in Alaska. Anchorage: Alaska Geological Society. 51-78.

KURZ, M.D., and BROOK, E.J. 1994. Surface exposure dating with cosmogenic nuclides. In: Beck, C., ed. Dating in exposed and surface contexts. Albuquerque: University of New Mexico Press. 139-159.

LAL, D. 1991. Cosmic ray labeling of erosion surfaces: In situ nuclide production rates and erosion rates. Earth and Planetary Science Letters 104:424-439.

NELSON, C.H. 1982. Late Pleistocene-Holocene transgressive sedimentation in deltaic and non-deltaic areas of the northeastern Bering epicontinental shelf. Geologie en Mijnbouw 61:5-27.

NELSON, C.H., HOPKINS, D.M., and SCHOLL, D.W. 1974. Tectonic setting and Cenozoic sedimentary history of the Bering Sea. In: Herman, Y., ed. Marine geology and oceanography of the Arctic seas. New York: Springer-Verlag. 119-140.

NISHIIZUMI, K., KOHL, C.P., ARNOLD, J.R., DORN, R., KLEIN, J., FINK, D., MIDDLETON, R., and LAL, D. 1993. Role of in situ cosmogenic nuclides ${ }^{10} \mathrm{Be}$ and ${ }^{26} \mathrm{Al}$ in the study of diverse geomorphic processes. Earth Surface Processes and Landforms 18:407-425.

PHILLIPS, F.M., LEAVY, B.D., JANNIK, N.O., ELMORE, D., and KUBIK, P.W. 1986. The accumulation of cosmogenic chlorine-36 in rocks: A method for surface exposure dating. Science 231:41-43.

PLAFKER, G., GILPIN, L.M., and LAHR, P. 1993. Plate 12. Neotectonic map of Alaska. In: Plafker, G., and Berg, H.C., eds. Geology of Alaska. Geology of North America (GNA-1). Geological Society of America, 1 sheet, scale 1:2500000.
PRIME LAB (PURDUE RARE ISOTOPE MEASUREMENT LABORATORY). 1995. Chemistry Operations Worksheets AW0010 and AW0011. Available from PRIME Lab, Purdue University, 1396 Physics Building, West Lafayette, Indiana 47907-1396, U.S.A.

REGER, R.D., and PÉWÉ, T.L. 1976. Cryoplanation terraces: Indicators of a permafrost environment. Quaternary Research 6:99- 109 .

SAINSBURY, C.L. 1967a. Quaternary geology of Western Seward Peninsula, Alaska. In: Hopkins, D.M., ed. The Bering land bridge. Stanford: Stanford University Press. 121-143.

. 1967b. Upper Pleistocene features in the Bering Strait area. U.S. Geological Survey Professional Paper 575-D:D203-D213.

. 1972. Geologic map of the Teller quadrangle, western Seward Peninsula, Alaska: U.S. Geological Survey Miscellaneous Investigations Series Map 1-685, 1 sheet, scale $1: 250000$.

SHARMA, G.D. 1974. Geological oceanography of the Bering Shelf. In: Herman, Y., ed. Marine geology and oceanography of the Arctic seas. New York: Springer-Verlag. 141-156.

SHER, A. 1995. Is there any real evidence for a huge ice sheet in east Siberia? Quaternary International 28:39-40.

SUGDEN, D.E., and WATTS, S.H. 1977. Tors, felsenmeer, and glaciation in northern Cumberland Peninsula, Baffin Island. Canadian Journal of Earth Sciences 14:2817-2823.

THORSON, R.M., and HAMILTON, T.D. 1986. Glacial geology of the Aleutian Islands. In: Hamilton, T.D., Reed, K.M., and Thorson, R.M., eds. Glaciation in Alaska. Anchorage: Alaska Geological Society. 171-191.

WORALL, D.M. 1991. Tectonic history of the Bering Sea and the evolution of Tertiary strike slip basins of the Bering shelf. Geological Society of America Special Paper 257.

ZREDA, M.G., and PHILLIPS, F.M. 1994. Surface exposure dating by cosmogenic chlorine-36 accumulation. In: Beck, C., ed. Dating in exposed and surface contexts. Albuquerque: University of New Mexico Press. 161-183.

ZREDA, M.G., PHILLIPS, F.M., ELMORE, D., KUBIK, P.W., SHARMA, P., and DORN, R.I. 1991. Cosmogenic chlorine-36 production rates in terrestrial rocks. Earth and Planetary Letters 105:94-109. 